JURNAL KETAHANAN NASIONAL

ISSN: 0853-9340 (Print), ISSN: 2527-9688 (Online)

Online sejak 28 Desember 2015 di: http://jurnal.ugm.ac.id/JKN

VOLUME 23

No. 1, 27 April 2017

Halaman 17-36

\title{
Kepemimpinan Pemuda Dalam Program Pemberdayaan Masyarakat Untuk Meningkatkan Ketahanan Ekonomi Keluarga (Studi Kepemimpinan Wawan Yuanda di Desa Tumiyang, Kecamatan Kebasen, Kabupaten Banyumas, Provinsi Jawa Tengah)
}

\author{
Helmy Shoim Pramudyarto \\ CV Jayashree \\ Email: kangshoim@yahoo.co.id \\ Armaidy Armawi \\ Fakultas Filsafat UGM \\ Email: armaidy@ugm.ac.id \\ Bagus Riyono \\ Fakultas Psikologi UGM \\ Email: bagus@ugm.ac.id
}

\begin{abstract}
The purpose of this study was to determined the leadership of Wawan Yuanda as a village chief in the community empowerment program through brick-making business and its implications for the the family economic resilience and to knew the obstacles faced in implementing community development programs such.

This research was a descriptive model of mixed methods or mixed method using concurrent transformative strategies by collecting data at one stage / phase of the study and at the same time to got a description or picture of the social realities that existed in the community which was then used to analyzed the Village Chief of leadership in the community empowerment program and its implications on family economic resilience.

The results showed that Wawan Yuanda as the village chief of Tumiyang Village had been successfully doing community empowerment program through making bricks. The success also had implications for villagers revenue thus increasing the economic resilience of the communities involved in the family business of making bricks.
\end{abstract}

Keyword: Youth Leadership, Community Development, Family Economic Resilience.

\section{ABSTRAK}

Tujuan dari penelitian ini yaitu untuk mengetahui kepemimpinan Wawan Yuanda sebagai kepala desa dalam program pemberdayaan masyarakat melalui usaha pembuatan batu bata serta implikasinya terhadap ketahanan ekonomi keluarga dan untuk mengetahui hambatan yang dihadapi dalam melaksanakan program pemberdayaan masyarakat tersebut..

Penelitian ini merupakan penelitian deskriptif dengan pendekatan model metode campuran atau mixed method dengan menggunakan Strategi Transformatif Konkuren dengan mengumpulkan data pada satu tahap/fase penelitian dan pada waktu yang sama untuk mendapatkan deskripsi atau gambaran dari realitas sosial yang ada di masyarakat yang kemudian untuk mengungkap tentang kepemimpinan Kepala Desa dalam program pemberdayaan masyarakat dan implikasinya terhadap ketahanan ekonomi keluarga.

Hasil penelitian menunjukkan bahwa Wawan Yuanda selaku Kepala Desa Tumiyang telah berhasil melakukan program pemberdayaan masyarakat melalui usaha batu bata. Keberhasilan tersebut juga berimplikasi terhadap pendapatan masyarakat sehingga meningkatkan ketahanan ekonomi keluarga masyarakat yang terlibat dalam usaha pembuatan batu bata

Kata Kunci : Kepemimpinan Pemuda, Pemberdayaan Masyarakat, Ketahanan Ekonomi Keluarga 


\section{PENGANTAR}

Terdapat satu fenomena menarik dari sebuah desa di Kabupaten Banyumas, yaitu yang terjadi di Desa Tumiyang, Kecamatan Kebasen. Dalam pemilihan kepala desa yang dilaksanakan 7 tahun yang lalu tepatnya pada Januari 2009 telah terpilih seorang pemuda berusia 25 tahun sebagai kepala desa. Pemuda tersebut bernama Wawan Yuanda. Kepala Desa terpilih ini dinobatkan menjadi kepala desa termuda di Indonesia (http://www.detiknews. com). Dia mampu mengalahkan lawannya yang notabene memiliki modal yang kuat dan usia lebih matang untuk berkompetisi dalam pemilihan kepala desa waktu itu. Sedangkan Wawan Yuanda adalah anak muda dari keluarga sederhana, belum bekerja dan tidak memiliki modal dana yang cukup untuk mencalonkan dalam pemilihan kepala desa serta masih menyelesaikan kuliah di Fakultas Pertanian Universitas Jendral Soedirman Purwokerto.

Dalam penelitian ini bermaksud untuk mendiskusikan tentang kepemimpinan seorang kepala desa muda yaitu Wawan Yuanda dalam melaksanakan program pemberdayaan masyarakat di Desa Tumiyang. Kemampuan Wawan Yuanda dalam memimpin Desa Tumiyang dalam melaksanakan pemberdayaan masyarakat menarik untuk diteliti karena dia menjabat sebagai kepala desa dalam usia muda. Kesuksesan kepemimpinan Wawan Yuanda tidak lepas dari kemampuannya dalam melaksanakan fungsi kepemimpinan.

Menurut Andisasmita (2006:226) yang dimaksud dengan fungsi kepemimpinan adalah memandu, menuntun, membimbing, memberi atau membangun motivasi kerja, mengemudikan organisasi, menjalin jaringan komunikasi yang baik, memberikan pengawasan yang efisien, dan membawa anggota organisasi kepada sasaran yang dituju.
Selain itu, Andisasmita berpendapat bahwa faktor kemampuan pemimpin desa merupakan hal yang penting dalam menciptakan partisipasi masyarakat dalam pembangunan desa. Karena itulah sejauh mana fungsi kepemimpinan seorang pemuda mampu untuk menghasilkan suatu hal yang baru untuk kemajuan desa yang dipimpinnya. Pemuda dikatakan sebagai agen perubahan apabila ia memiliki kemampuan untuk berinovasi. Karena dengan inovasi sesuatu yang baru akan muncul sehingga inilah yang menjadi keunggulan kepemimpinan seorang pemuda.

Salah satu inovasi kepemimpinan Wawan Yuanda yaitu program kerja pemberdayaan ekonomi masyarakat melalui pembuatan batu bata. Pemberdayaan masyarakat sendiri memiliki kaitan erat dengan konsep alternatif pembangunan. Konsep ini menekankan otonomi pengambilan keputusan suatu kelompok masyarakat yang berlandaskan pada sumber daya pribadi, partisipasi, demokrasi, dan pembelajaran sosial melalui pengalaman langsung. Fokusnya adalah lokalitas, karena civil society lebih siap diberdayakan lewat isu-isu lokal. Karena itu, pemberdayaan masyarakat tidak hanya sebatas ekonomi, tapi juga politik, sehingga masyarakat memiliki posisi tawar secara nasional maupun internasional (Sumodiningrat, 2007: 29).

Dalam UU Desa yang disahkan akhir tahun 2013, dinyatakan bahwa Pemberdayaan MasyarakatDesa adalahupaya mengembangkan kemandirian dan kesejahteraan masyarakat dengan meningkatkan pengetahuan, sikap, keterampilan, perilaku, kemampuan, kesadaran, serta memanfaatkan sumber daya melalui penetapan kebijakan, program, kegiatan, dan pendampingan yang sesuai dengan esensi masalah dan prioritas kebutuhan masyarakat desa. 
Helmy Shoim Pramudyarto, Armaidy Armawi, Bagus Riyono -- Kepemimpinan Pemuda Dalam Program Pemberdayaan Masyarakat Untuk Meningkatkan Ketahanan Ekonomi Keluarga (Studi Kepemimpinan Wawan Yuanda di Desa Tumiyang, Kecamatan Kebasen, Kabupaten Banyumas, Provinsi Jawa Tengah)

Penelitian ini merupakan penelitian yang menggunakan metode campuran atau mixed method untuk mengungkap tentang kepemimpinan kepala desa dalam program pemberdayaan masyarakat dan implikasinya terhadap ketahanan ekonomi keluarga. Strategi transformatif konkuren digunakan dalam metode mixed method di penelitian ini, artinya penelitian ini dilakukan dengan mengumpulkan data pada satu tahap/ fase penelitian dan pada waktu yang sama untuk mendapatkan deskripsi atau gambaran dari realitas sosial yang ada di masyarakat (Creswell, 2009: 324). Data didapatkan melalui wawancara, dokumentasi, pembagian kuesioner, telaah pustaka dan pengamatan langsung.

Penelitian ini melibatkan orang yang terlibat langsung dalam program pemberdayaan masyarakat melalui usaha pembuatan batu bata yaitu sebanyak 8 (delapan) orang pemilik usaha dan 21 (dua puluh satu) orang pekerja. Selain itu informan yang terlibat dalam penelitian ini ialah 8 (delapan) orang tokoh masyarakat yang sekiranya dianggap memiliki informasi mengenai kepemimpinan Wawan Yuanda serta program yang dijalankan. Penentuan informan tersebut sangat diperlukan karena dalam menentukan tingkat validitas data peneliti menggunakan cara triangulasi sumber.

Tujuan dari penelitian ini yaitu untuk mengetahui kepemimpinan Wawan Yuanda sebagai kepala desa dalam program pemberdayaan masyarakat melalui usaha pembuatan batu bata serta implikasinya terhadap ketahanan ekonomi keluarga dan untuk mengetahui hambatan yang dihadapi dalam melaksanakan program pemberdayaan masyarakat tersebut.

\section{PEMBAHASAN \\ Profil Desa Tumiyang}

Desa Tumiyang secara administratif termasuk dalam wilayah Kecamatan Kebasen, Kabuten Banyumas. Desa Tumiyang berjarak $12 \mathrm{Km}$ dari pusat pemerintahan Kabupaten Banyumas dengan waktu tempuh sekitar 30 menit. Desa Tumiyang terdiri dari 2 dusun, Kadus I dan Kadus II, juga terdapat 2 grumbul yaitu grumbul Tumiyang Lor dan grumbul Tumiyang Kidul, secara administratif terbagi dalam 3 RW. Luas wilayah Desa Tumiyang adalah 475,375 Ha dengan batas-batas desa sebagai berikut: sebelah Utara Desa Mandirancan, sebelah Timur Desa Negara, sebelah Selatan Desa Gambarsari, sebelah Barat Sungai Serayu (Kecamatan Rawalo). Secara lebih rinci profil Desa Tumiyang dapat djelaskan di bawah ini.

Pertama, topografi. Desa Tumiyang memiliki daerah pegunungan dan dataran. untuk daerah pegunungan mempunyai ketinggian sekitar 200-450 m di atas permukaan laut (dpl). Sedangkan untuk daerah dataran rata-rata berkisar $18 \mathrm{~m}$ di atas permukaan laut (dpl). Suhu di Desa Tumiyang cukup panas dengan kelembaban udara sedang.

Kedua, jumlah penduduk. Desa Tumiyang sampai dengan Nopember 2013 memiliki jumlah penduduk 1572 jiwa yang terdiri dari 793 laki-laki dan 779 perempuan dengan jumlah kepala keluarga (KK) $368 \mathrm{KK}$.

Ketiga, mata pencaharian. Penduduk Desa Tumiyang sebagaian besar adalah bermata pencaharian sebagai petani, buruh dan selebihnya adalah pengusaha, pedagang, pegawai swasta, PNS/ABRI dan lain-lain. sebagain penduduk ada yang merantau ke kota besar seperti Jakarta, Bandung, Surabaya dan kota besar lainnya.

Keempat, tingkat pendidikan. Tingkat pendidikan penduduk Desa Tumiyang secara 
umum tergolong rendah. Hal ini pada umumnya disebabkan karena masih kurangnya kesadaran masyarakat akan pentingnya pendidikan di samping faktor lain yaitu maslaah mahalnya biaya pendidikan. Sebagian besar penduduk Desa Tumiyang hanyalah tamatan Sekolah Dasar (SD) selanjutnya adalah SLTP, SLTA, Perguruan Tinggi. Fakta di lapangan bahwa penduduk desa sebenarnya masih didominasi oleh usia produktif tapi disayangkan tingkat pendidikan masih sangat rendah, implikasinya mayoritas penduduk desa bekerja sebagai buruh. Maka bisa dipahami jika kemudian Desa Tumiyang tertinggal jauh dengan desadesa di sekitarnya. Kondisi penduduk Desa Tumiyang yang tertinggal secara pendidikan dan ekonomi dengan mata pencaharian yang masih didominasi petani bahkan mayoritas buruh tani.

\section{Latar Belakang Program Pemberdayaan Masyarakat Melalui Usaha Pembuatan Batu Bata}

Pada awalnya program pemberdayaan masyarakat melalui usaha pembuatan batu bata merupakan kegelisahan Wawan Yuanda meliha kondisi desa yang hampir sepanjang jalan kecamatan yang melintasi Desa Tumiyang, mayoritas tebing yang sering sekali longsor. Berawal dari kegelisahan itu muncul ide untuk menaikkan jalan tersebut menjadi jalan kabupaten dengan cara mengepras tebing tersebut agar jalan dapat diperlebar. Ide tersebut mendapat tanggapan yang baik dari Dinas Pekerjaan Umum Kabupaten Banyumas.

Setelah mendapatkan tanggapan dari Dinas Pekerjaan Umum Kabupaten Banyumas maka segera disusun izin-izin untuk melakukan pengeprasan tebing. Izin yang digunakan untuk mensiasati kondisi ialah izin penanggulangan bencana kepada dinas terkait sehingga tebing harus dikepras. Untuk mengurusi pengeprasan ini juga dibentuk BUMDes yang khusus mengurusi material hasil keprasan agar dapat menjadi pendapatan untuk desa. Warga juga bisa memanfaatkan tanah untuk bahan baku pembuatan batu bata. Selain itu, ada juga warga yang bekerja menjadi pekerja penambangan maupun membuka warung di sekitar penambangan.

Pembuatan batu bata merupakan program pertama Wawan Yuanda yang masih berjalan sampai saat ini. Pada saat menggerakkan warga untuk ikut dalam usaha pembuatan batu bata ini Wawan Yuanda diuntungkan oleh kondisi warga yang masih sangat percaya patronase termasuk kepercayaan masyarakat kepada orang yang dianggap baik dan bersih, sehingga hal tersebut dapat memudahkan untuk menggerakkan warga. Ketika ia memberikan contoh kepada warga untuk usaha pembuatan batu bata, ada beberapa orang warga yang tergerakkan. Merekalah yang menjadi cikal bakal pengusaha batu bata.

Dalam usaha pembuatan batu bata tersebut terdapat beberapa tahapan yang dilalui.

Pertama, kegiatan pra produksi. Aktivitas pada kegiatan pra produksi meliputi (1) Pembuatan bedeng. Bedeng semacam bangunan semi permanen yang digunakan untuk menyimpan batu bata yang selesai dijemur dan siap dibakar. Bedeng juga berfungsi sebagai tempat untuk menyusun batu bata sehingga membentuk suatu susunan yang mampu mengoptimalkan panas pada waktu proses pembakaran. (2) Penyiapan lahan. Proses penyiapan lahan dilakukan agar lahan yang akan digunakan telah dipastikan bersih dan rata sehingga siap digunakan untuk kegiatan produksi batu bata. (3) Pembelian 
Helmy Shoim Pramudyarto, Armaidy Armawi, Bagus Riyono -- Kepemimpinan Pemuda Dalam Program Pemberdayaan Masyarakat Untuk Meningkatkan Ketahanan Ekonomi Keluarga (Studi Kepemimpinan Wawan Yuanda di Desa Tumiyang, Kecamatan Kebasen, Kabupaten Banyumas, Provinsi Jawa Tengah)

peralatan. Pada proses produksi batu bata tidak banyak membutuhkan peralatan. Peralatan yang digunakan hanya alat cetak, cangkul, sabit (arit) kerik dan sorok. Masing-masing alat memiliki fungsi masing-masing.

Kedua, kegiatan produksi. Produk batu bata yang diproduksi memiliki ukuran tebal $5 \mathrm{~cm}$, panjang $23 \mathrm{~cm}$ dan lebar $12 \mathrm{~cm}$. Pada satu kali proses cetak, satu alat cetak mampu memproduksi antara 10 sampai dengan 12 buah. Tahapan yang dilalui dalam proses produksi ialah pencetakan, pengeringan, pengerikan, penyusunan dan pembakaran. Rata-rata waktu pencetakan yang diperlukan ialah 7-10 hari. Setelah proses pencetakan, batu bata dikeringkan dengan cara dijemur dengan bantuan sinar matahari. Proses pengeringan ini berlangsung selama 7-15 hari sangat tergantung dari cuaca. Setelah batu bata dirasa kering kemudian proses selanjutnya ialah pengerikan. Tujuan dari proses ini adalah untuk menghilangkan bagian-bagian sisi luar batu bata yang kurang halus. Proses ini akan memakan waktu kurang dari 7 hari biasanya. Pengerikan batu bata berbarengan dengan proses penataan agar batu bata membentuk susunan tertentu dan siap dibakar. Jadi batu bata yang sudah dikerik kemudian langsung disusun membentuk susunan tertentu agar pembakaran dapat maksimal. Proses pembakaran sampai dengan siap untuk dibongkar bisa memakan waktu selama 5 hari.

Ketiga, pasca produksi. Kegiatan pasca produksi meliputi kegiatan pemasaran dan penjualan batu bata. Dalam usaha pembuatan batu bata di Desa Tumiyang, ada beberapa pola pemasaran dan penjualan batu bata hasil produksi, yaitu dengan cara (1) Penjualan langsung. Pada penjualan langsung ini, konsumen biasanya berasal dari masyarakat umum dan para pemborong bangunan.
(2) Penjualan melalui toko. Sedangkan penjualan melalui toko, biasanya toko yang membutuhkan pasokan dari usaha pembuatan batu bata Desa Tumiyang ialah toko bangunan yang berada di sekitar Kecamatan Patikraja, Kebasen, Maos dan Sampang.

\section{Hambatan Dalam Menjalankan Usaha}

Dalam menjalankan usaha pembuatan batu bata, masyarakat Desa Tumiyang menemui berbagai kendala.

Pertama, kendala keuangan. Adapun kendala keuangan yang dihadapi oleh masyarakat utamanya para pemilik usaha pembuatan batu bata ialah kendala klasik yang sering dialami terutama oleh pengusaha kecil. Walaupun para pemilik usaha mampu membuka usaha dengan modal sendiri namun dalam perjalanannya dikarenakan manajemen pengelolaan keuangan yang belum baik maka terkadang proses produksi terhambat karena tidak tersedianya modal. Hal semacam ini terjadi karena modal usaha seringkali masih tercampur dengan keuangan pribadi para pemilik usaha.

Kedua, kendala cuaca. Cuaca merupakan salah satu faktor kunci dalam keberhasilan proses produksi batu bata. Hal ini dikarenakan proses pengeringan batu bata masih mengandalkan bantuan sinar matahari. Cepat atau lambatnya proses produksi dipengaruhi oleh kondisi sinar matahari. Semakin panas dan lama sinar matahari maka semakin cepat proses produksi, begitu juga sebaliknya. Ketergantungan terhadap sinar matahari ini belum pernah dicarikan solusi karena memang itulah satu-satunya sarana untuk mengeringkan batu bata. Akan tetapi sekarang para pemilik usaha menyiapkan semacam bangunan khusus yang beratapkan plastik agar batu bata dapat terhindar dari hujan dan tetap mendapatkan sinar matahari apabila ada. 
Ketiga, kendala bahan baku. Seiring sudah akan selesainya proyek pengeprasan tebing jalan di Desa Tumiyang maka semakin sedikit pula bahan baku yang dapat dimanfaatkan. Karena tanah tidak dapat diproduksi maka kendala bahan baku ini menjadi ancaman terhadap keberlangsungan usaha. Saat ini selain mengandalkan dari tanah keprasan tebing, pemilik usaha pembuatan batu bata juga memanfaatkan tanah di sekitar tobong mereka. Selain itu, mereka juga mendatangkan tanah dari daerah Kebasen, Maos bahkan sampai Sampang.

Keempat, kendala pemasaran. Dalam dunia usaha, selain permasalahan modal, permasalahan klasik lainnya ialah masalah pemasaran. Hasil produksi batu bata sampai saat ini masih mengandalkan penjualan langsung kepada konsumen akhir. Para pemilik usaha tidak berani untuk melakukan kontrak kerjasama dengan kontraktor atau toko bangunan dikarenakan belum mampu memastikan proses produksi sesuai dengan kesepakatan perjanjian kerjasama. Sebagai contoh ialah soal waktu. Dikarenakan masih memiliki kendala produksi yaitu cuaca, seringkali membuat para pemilik usaha enggan untuk melakukan kerjasama yang sifatnya pasti.

\section{Kepemimpinan Kepala Desa Tumiyang}

Kepemimpinan Kepala Desa Tumiyang dalam pemberdayaan masyarakat melalui pembuatan batu bata dapat dijelaskan sebagai berikut.

Pertama, aspek motivator. Dari tabulasi kuesioner yang dibagikan kepada pekerja dalam usaha pembuatan batu bata yaitu sebanyak 21 warga dapat disimpulkan bahwa kepemimpinan kepala desa mampu meningkatkan kemampuan dan kapasitas warga. Wawancara dengan
Supardi menegaskan bahwa Wawan Yuanda merupakan sosok kepala desa yang memiliki ide cemerlang, sehingga terpilih sebagai kepala desa, sebagaimana petikan wawancara berikut.

\section{"Saya dulu milih pak Wawan ya karena dia pinter, banyak gagasannya buat kemajuan warga, itu ide batu bata sudah disampaikan pas pemilihan Lurah (Kepala Desa) (wawancara 21 Oktober 2015)"}

Demikian halnya yang disampaikan oleh Sirun berikut ini.

"ya awale saya ragu mas mau ikut-ikutan mas Wawan buat batu bata tapi mas Wawan selalu memberikan dorongan semangat, kan saya dulu juga bingung harus mulai dari mana, ya akhirnya dengan modal seadanya, Alhamdulillah bisa jalan sampai sekarang (wawancara 21 Oktober 2015).

Dari beberapa pernyataan hasil tabulasi kuesioner serta wawancara penelitian di atas dapat disimpulkan bahwa kepemimpinan Wawan Yuanda dalam program pemberdayaan masyarakat mampu memberikan dorongan motivasi kepada masyarakat sehingga kemampuan dan kapasitas masyarakat meningkat. Keterlibatan aktif masyarakat merupakan wujud bahwa Wawan Yuanda mampu untuk memberikan dorongan motivasi kepada warganya. Kesimpulan ini selaras dengan kesimpulan dalam teori yang kepemimpinan yang dikemukakan oleh Bass (1985), dimana pemimpin yang inovatif ialah pemimpin yang mampu untuk memberikan sifat-sifat keteladanan (idealized influence) serta menjadi inspirasi (inspirational motivation) bagi pengikutnya sehingga mau untuk bekerja serta memiliki inspirasi semangat dalam bekerja (Ancok, 2012: 130-132). Hal ini yang nampak dalam 
Helmy Shoim Pramudyarto, Armaidy Armawi, Bagus Riyono -- Kepemimpinan Pemuda Dalam Program Pemberdayaan Masyarakat Untuk Meningkatkan Ketahanan Ekonomi Keluarga (Studi Kepemimpinan Wawan Yuanda di Desa Tumiyang, Kecamatan Kebasen, Kabupaten Banyumas, Provinsi Jawa Tengah)

kepemimpinan Wawan Yuanda dimana ia memberikan pengaruh dan inspirasi kepada warga untuk mau diajak terlibat dalam program pemberdayaan warga untuk melakukan aktivitas dalam program pemberdayaan.

Kedua, aspek administrator. Berdasarkan hasil tabulasi kuesioner yang dibagikan kepada warga yang terlibat dalam usaha pembuatan batu bata dapat disampaikan hasil bahwa potensi yang dimiliki masyarakat desa dapat tergali dan tertata dengan baik. Hal tersebut selaras dengan pernyataan Sekretaris Desa Tumiyang juga mengatakan seperti di bawah ini.

"Ada perbedaan antara Pak Wawan dengan Kades sebelum-sebelumnya, kepala desa sekarang lebih banyak membangun jaringan keluar, kalau yang kepala desa yg dulu lebih condong ke internal sehingga minim jaringan. Secara umum baik, beliau sifatnya fleksibel karena secara umur beliau yang paling muda di antara perangkat desa yang ada. Jadi santai pembawaannya, serasa sepantaran tidak ada jarak dengan perangkat dan masyarakat. Sekarang ini beliau menerapkan pendelegasian dan pembagian tugas kepada perangkat desa,ya saya melihatnya semua perangkat bekerja dengan optimal dan baik (wawancara 21 Oktober 2015)"

Demikian halnya pernyataan yang disampaikan Sarkim berikut ini.

"sebenere (sebenarnya) warga Tumiyang itu banyak yang bisa bikin (batu) bata, ya dulu kalo mau bikin rumah, ya siap-siap bikin (batu bata) sendiri. Pak Wawan kayane (sepertinya) ngerti (mengetahui) kalo warga banyak yang bisa itu (membuat batu bata) (wawancara 20 Oktober 2015)"

Bass dalam teorinya menyimpulkan bahwa salah satu ciri kepemimpinan inovatif ialah dimana pemimpin yang mampu merangsang dan mengembangkan potensi pengikutnya dengan cara memberikan tantangan dan fasilitas agar muncul gagasan kreatif dan inovatif (Ancok, 2012: 131). Hal ini selaras dengan kesimpulan dari hasil penelitian ini bahwa kepemimpinan Wawan Yuanda dalam program pemberdayaan masyarakat mampu menggali dan memunculkan potensi yang dimiliki masyarakat Desa Tumiyang.

Ketiga, aspek koordinator. Tabulasi dari hasil kuesioner yang dibagikan kepada 21 orang pekerja pada usaha pembuatan batu bata menunjukkan hasil bahwa pelaksanaan program pemberdayaan masyarakat melalui usaha pembuatan batu bata ini terkoordinasikan dengan baik. Hasil tabulasi tersebut menguatkan hasil dari wawancara yang diungkapkan oleh Suryawinata berikut ini.

"kalo ada sensus itu RT RW termasuk ikut menerima dana sensusnya, tapi yang dulu engga, bedanya seperti itu, kalo dulu ada sensus dari RT ga tau kalo itu ada dananya, kalo sekarang ikut menerima loh, karena prinsipnya dia wong $R T$ yang gawe, $R T$ yang kerja, artinya yang bekerja sensus kan $R T R W$ yang nyensus kan dari $R T$ seperti itu. Kalo sekarang dikasih dana sensus, prinsipnya dia bahwa RT yang bekerja ikut-ikut nerima, kalo yang dulu ya ga tau pas sensus ada dananya (wawancara 21 Oktober 2015)"

Pendapat yang mendukung hal tersebut terlihat dari hasil wawancara berikut ini.

"Pak Wawan itu orang yang gampang akrab, ngobrol sama dia kayak bukan ngobrol sama lurah, enak pokoknya diajak ngobrol, mau mendengar dan ngasih masukan buat usaha (batu) bata saya" (wawancara dengan Ruslan, 21 Oktober 2015) 
Bass menyatakan dalam kesimpulan teorinya bahwa pemimpinan yang inovatif ialah pemimpin yang memperhatikan kebutuhan pengikutnya dan membantu mereka agar dapat berkembang (Ancok, 2012: 132). Hal ini selaras dengan temuan penelitian ini dimana dari mayoritas jawaban warga tersebut di atas maka dapat disimpulkan bahwa kepemimpinan Wawan Yuanda dalam program pemberdayaan masyarakat mampu menjadikan aktivitas usaha batu bata masyarakat Desa Tumiyang terkoordinasi dengan baik. Dalam konteks yang lain, seorang Wawan Yuanda juga merupakan kepala desa yang mampu menjadi koordinator yang baik bagi warganya.

Berdasarkan uraian dan fakta yang disajikan di atas dapat disimpulkan bahwa seorang Wawan Yuanda merupakan sosok pemimpin dalam hal ini sebagai kepala desa yang kepemimpinnya mampu bertindak sebagai motivator, administrator dan koordinator. Program pemberdayaan ini berjalan jelas karena adanya ide dan contoh nyata dari Wawan Yuanda sehingga mampu menjadi penyemangat bagi masyarakat Desa Tumiyang. Selain itu, Wawan Yuanda mampu bertindak merangkul warga yang memiliki minat dan potensi untuk diberdayakan melalui usaha pembuatan batu bata ini. Dalam konteks koordinator, Wawan Yuanda mampu berkomunikasi dan membantu masyarakat dalam menerapkan pemberdayaan masyarakat yang digagasnya sehingga warga dapat menjalankan usahanya. Kesimpulan ini selaras dengan kesimpulan penelitian de Jong \& Hartog yang menyimpulkan bahwa kepemimpinan inovatif terkait dengan dua hal yaitu pemunculan ide (idea generation) dan penerapan ide (idea application) (Ancok, 2012: 133).

\section{Tingkat Keberdayaan Masyarakat}

Berdasarkan teori mengenai tingkat keberdayaan masyarakat dalam program pemberdayaan masyarakat yang disampaikan oleh Suharto dalam (Mardikanto 2011:290) menyebutkan bahwa untuk mengetahui keberhasilan tingkat keberdayaan dari program pemberdayaan masyarakat maka perlu dikaitkan dengan empat dimensi kekuasaan, yaitu : kekuasaan di dalam (power within), kekuasaan untuk (power to), kekuasaan atas (power over), dan kekuasaan dengan (power with). Dari kuesioner yang peneliti bagikan didapatkan data tentang keberdayaan masyarakat dapat disampaikan hasil sebagai berikut.

Pertama, kekuasaan di dalam (power within). Dari tabulasi hasil kuesioner dapat disampaikan hasil bahwa warga memiliki kesadaran dan keinginan untuk berubah. Hasil tersebut senada dengan hasil wawancara yang diungkapkan oleh $\mathrm{H}$. Budi sebagaimana berikut ini.

"Batu bata itu program pak Kades, beliau turun langsung dengan mencontohkan langsung, beliau buat langsung juga menampung batu bata dari warga untuk disalurkan ke daerah ke daerah Cilacap dan Purwokerto. Program itu sangat dirasakan mengurangi pengangguran, banyak warga yang mau untuk gabung setelah melihat pak Kades memulai membuat (batu) bata. Kades awalnya menalangi dulu, saya dengar beliau juga merugi karena (spesifikasi) bata tidak sesuai permintaan pemborong (wawancara 20 Oktober 2015)"

Pernyataan tersebut selaras dengan hasil wawancara berikut ini.

"pas Pak Wawan buat batu bata, awalnya saya tidak tertarik, tapi setelah melihat hasilnya kok kayane (sepertinya) ada hasilnya, ya coba, Alhamdulillah jalan 
Helmy Shoim Pramudyarto, Armaidy Armawi, Bagus Riyono -- Kepemimpinan Pemuda Dalam Program Pemberdayaan Masyarakat Untuk Meningkatkan Ketahanan Ekonomi Keluarga (Studi Kepemimpinan Wawan Yuanda di Desa Tumiyang, Kecamatan Kebasen, Kabupaten Banyumas, Provinsi Jawa Tengah)

sampai sekarang (wawancara dengan Nidam, 22 Oktober 2015)

Kedua, kekuasaan untuk (power to). Dari tabulasi data hasil kuesioner dapat disampaikan hasil bahwa terjadi peningkatan kemampuan dan akses warga terhadap program. Hal tersebut selaras dengan pendapat Sudar di bawah ini.

"Pak Wawan itu dulu ngomong ke semua warga setahu saya, siapa yang mau untuk diajak usaha batu bata, ya lewat obrolan, kadang juga datang di rapat-rapat warga, kayak RT(wawancara 22 Oktober 2015)

Wawancara dengan Giman, seorang pemilik tobong batu bata, menguatkan hasil dari pernyataan tersebut. Tampak pada wawancara berikut ini.

"Yang saya rasakan sendiri ya program batu bata itu bisa meningkatkan penghasilan dan ketrampilan warga. Saya juga salut dengan kepala desa yang mau nanggung rugi karena awalnya batu bata yang diproduksi warga tidak sesuai dengan keinginan pembeli. Selain itu kades juga menjadi contoh yang baik bagi warga dengan ide dan aktivitasnya. Ya secara tidak langsung batu bata menyerap banyak tenaga kerja, di tempat saya saja saya dibantu dua orang pekerja (22 Oktober 2015 ).

Ketiga, kekuasaan atas (power over). Hasil wawancara menunjukkan bahwa warga mampu melakukan kendali atas usaha dan mengatasi masalah serta mendapat manfaat dari usaha pembuatan batu bata. Hasil ini seperti apa yang disampaikan oleh Ruslan, seperti kutipan wawancara berikut ini.

"Dulu kan tanah itu diambil dari hasil keprasan gunung (baca : tebing di jalan desa) tapi ya sekarang tidak bisa hanya ambil tanah dari situ. Saya beli tanah dari daerah Maos (Kabupaten Cilacap) (21 Oktober 2015)"

Sedangkan dari wawancara dengan Sarkim didapatkan informasi sebagai beriku.

"Alhamdulillah mas, dari usaha ini bisa buat dandan (membenahi) rumah, membelikan anak saya motor (untuk) ke sekolah(wawancara 21 Oktober 2015)"

Keempat, kekuasaan dengan (power with). Dari hasil tabulasi kuesioner dapat ditampikan hasil bahwa terjalin kerjasama dan soliditas warga dalam usaha pembuatan batu bata. Hal tersebut seperti halnya yang terungkap dalam wawancara dengan Wawan Yuanda berikut ini.

"Awalnya warga sering mengadukan permasalahan-permasalahan tentang usaha (batu) bata, ya soal tanah (bahan baku), soal penjualan dan lain sebagainya. Saya ajak ngobrol mereka, kita kumpulkan, akhirnya jadi kebiasaan, kalau ada masalah, coba dirembug bareng-bareng, dicari solusi (wawancara 19 Oktober 2015)"

Hal senada juga diungkapkan oleh Supardi sebagai berikut.

"kalau ada masalah dari masyarakat, kemudian diadukan ke kepala desa ya langsung diatasi. Biasanya seperti itu, dirembug, dicarikan solusi (wawancara 21 Oktober 2015)"

\section{Implikasinya Terhadap Peningkatan Ketahanan Ekonomi Keluarga \\ Pendapatan Pemilik Usaha}

Dalam mengukur pendapatan usaha dari pengusaha pembuatan batu bata ini, peneliti memakai rumus sebagai berikut : $\mathrm{T}$ $=$ Penjualan $-($ Biaya bahan baku + biaya penyusutan + biaya tenaga kerja). Berdasarkan 
rumus tersebut, besarnya penghasilan seorang pengusaha sangat dipengaruhi oleh kapasitas produksi dalam usaha pembuatan batu bata. Setiap pengusaha memiliki kapasitas yang berbeda, hal ini sangat dipengaruhi oleh luas tempat produksi batu bata.

Untuk menghitung pendapatan usaha dalam pembuatan batu ini maka diperlukan informasi mengenai biayabiaya yang muncul dalam kegiatan usaha. Biaya tersebut meliputi biaya penyusutan tobong dan alat, biaya perawatan, biaya bahan baku tanah, biaya bahan baku kayu, biaya bahan baku dan biaya tenaga kerja.
Sedangkan informasi lain yang dibutuhkan ialah mengenai kuantitas batu bata yang dihasilkan dalam satu proses produksi serta harga jual batu bata per buahnya, sehingga untuk menghitung pendapatan usaha dapat dilakukan dengan rumus berikut: $\boldsymbol{\pi}=\mathbf{T R}$ - TC (Keterangan : $\pi=$ pendapatan usaha; $\mathrm{TR}=$ Total Penerimaan $(\mathrm{Q} \times \mathrm{P}) ; \mathrm{TC}=$ Total Biaya yang dikeluarkan).

Secara rinci pendapatan pemilik usaha dapat dilihat dalam tabel 1 di bawah ini.

Sedang proporsi pendapaatan terhadap penerimaan dapat dilihat pada tabel 2 di bawah ini.

Tabel 1

Perhitungan Pendapatan Usaha

\begin{tabular}{|c|c|c|c|c|c|c|c|c|c|c|c|c|c|}
\hline No & Nama & $\begin{array}{c}\text { Biaya } \\
\text { Penyusutan } \\
\text { Tabung dan } \\
\text { Alat*(Rp) }\end{array}$ & $\begin{array}{c}\text { Biaya } \\
\text { Perawatan } \\
\text { (Rp) }\end{array}$ & $\begin{array}{c}\text { Biaya } \\
\text { Bahan } \\
\text { Baku } \\
\text { Tanah } \\
\text { (Rp) }\end{array}$ & $\begin{array}{l}\text { Biaya } \\
\text { Bahan } \\
\text { Baku } \\
\text { Kayu } \\
\text { (Rp) }\end{array}$ & $\begin{array}{c}\text { Biaya } \\
\text { Bahan } \\
\text { Baku } \\
\text { Sekam } \\
\text { (Rp) }\end{array}$ & $\begin{array}{l}\text { Total } \\
\text { Biaya } \\
\text { Tenaga } \\
\text { Kerja } \\
\text { (Rp) }\end{array}$ & $\begin{array}{c}\text { Total } \\
\text { Biaya } \\
\text { Cetak } \\
(\mathrm{Rp})\end{array}$ & $\begin{array}{l}\text { Total } \\
\text { Biaya } \\
\text { (TC) } \\
\text { Rp }\end{array}$ & $\begin{array}{c}\text { Kuantitas } \\
\text { Produksi } \\
\text { (Q) }\end{array}$ & $\begin{array}{c}\text { Harga } \\
\text { Jual/ } \\
\text { buah } \\
\text { (p) } \\
\text { (RP) }\end{array}$ & $\begin{array}{c}\text { Total } \\
\text { Penerimaan } \\
\text { (TR) } \\
\text { (Rp) }\end{array}$ & $\begin{array}{c}\text { Pendapatan } \\
(\mathrm{x}=\mathrm{TR}-\mathrm{TC}) \\
(\mathrm{Rp})\end{array}$ \\
\hline 1 & Nidam & 40.000 & 100.000 & 330.000 & 900.000 & 500.000 & 2.400 .000 & 550.000 & 4.820 .000 & 11.000 & 650 & 7.150 .000 & 2.330 .000 \\
\hline 2 & Sarkim & 100.000 & 200.000 & 600000 & 1.300 .000 & 1.000 .000 & 3.600 .000 & 850.000 & 7.650 .000 & 17000 & 650 & 11.050 .000 & 3.400 .000 \\
\hline 3 & Ruslan & 65.000 & 150.000 & 450.000 & 900.000 & 500.000 & 3.600 .000 & 700.000 & 6.365 .000 & 14.000 & 650 & 9.100 .000 & 2.735 .000 \\
\hline 4 & Ranu M & 85.000 & 160.000 & 480.000 & 900.000 & 500.000 & 3.600 .000 & 750.000 & 6.475 .000 & 15.000 & 650 & 9.750 .000 & 3.275 .000 \\
\hline 5 & Sarwin & 65.000 & 150.000 & 450.000 & 900.000 & 500.000 & 3600.000 & 700.000 & 6.365 .000 & 14.000 & 650 & 9.100 .000 & 2.755 .000 \\
\hline 6. & Giman & 85.000 & 200.000 & 600.000 & 1.300 .000 & 1.000 .000 & 3.600 .000 & 900.000 & 7.685 .000 & 17.000 & 650 & 11.050 .000 & 1.365 .000 \\
\hline 7. & Sudar & 50.000 & 125.000 & 390.000 & 900.000 & 500.000 & 2.400 .000 & 600.000 & 4.965 .000 & 12.000 & 650 & 7.800 .000 & 2.365 .000 \\
\hline
\end{tabular}

Sumber data: diolah dari hasil kuesioner dan wawancara.

Tabel.2

Proporsi Pendapatan terhadap Penerimaan

\begin{tabular}{cccccc}
\hline No & Nama & $\begin{array}{c}\text { Total Penerimaan } \\
(\mathrm{TR})\end{array}$ & $\begin{array}{c}\text { Total Biaya Produksi } \\
(\mathrm{TC})\end{array}$ & $\begin{array}{c}\text { Pendapatan Usaha } \\
(\mathrm{a}=\mathrm{TR}=\mathrm{TC}) \\
(\mathrm{Rp})\end{array}$ & $\begin{array}{c}\text { Proporsi Keuntungan } \\
\text { terhadap Pendapatan } \\
(5 \%)\end{array}$ \\
\hline 1 & Ngidam & 7.150 .000 & 4.820 .000 & 2.330 .000 & 33 \\
2. & Sarkim & 11.050 .000 & 7.650 .000 & 3.400 .000 & 30 \\
3. & Ruslan & 9.100 .000 & 6.365 .000 & 3.735 .000 & 30 \\
4. & Ranu M & 9.750 .000 & 6.475 .000 & 3.275 .000 & 34 \\
5. & Sarwin & 9.100 .000 & 6.365 .000 & 2.735 .000 & 30 \\
6. & Giman & 11.050 .000 & 7.685 .000 & 3.365 .000 & 30 \\
7. & Sudar & 7.800 .000 & 4.965 .000 & 2.835 .000 & 36 \\
8 & Supardi & 7.800 .000 & 5.035 .000 & 2.765 .000 & 35 \\
\hline
\end{tabular}

Sumber: diolah hasil kuesioner dan wawancara 
Helmy Shoim Pramudyarto, Armaidy Armawi, Bagus Riyono -- Kepemimpinan Pemuda Dalam Program Pemberdayaan Masyarakat Untuk Meningkatkan Ketahanan Ekonomi Keluarga (Studi Kepemimpinan Wawan Yuanda di Desa Tumiyang, Kecamatan Kebasen, Kabupaten Banyumas, Provinsi Jawa Tengah)

\section{Pendapatan Pekerja}

Para pekerja dalam usaha pembuatan batu bata di Desa Tumiyang bekerja selama 6 hari dalam satu minggu dan dalam satu bulan mereke bekerja selama 4 minggu. Cara pengupahan yang dilakukan dalam usaha pembuatan batu bata ialah upah mingguan dimana dalam satu hari pekerja menerima upah sebesar Rp. 50.000,-. (Lima puluh ribu rupiah) Penghitungan upahnya menjadi demikian: Upah 1 bulan $=6$ hari $\mathrm{x}$
Rp.50.000,- x 4 minggu = Rp. 1.200.000,,(Satu juta dua ratus rupiah) sehingga dalam satu bulan pekerja menerima upah sebesar Rp. 1.200.000,-.(Satu juta dua ratus rupiah) Selain dari upah tersebut pekerja masih mendapatkan upah tambahan berupa upah pencetakan batu bata yaitu Rp. 50,- / buah. Biasanya upah pencetakan batu bata tersebut akan dibagi rata tiap pekerja dalam satu tobong. Tabel 3 berikut ini adalah data upah pekerja dari usaha pembuatan batu bata.

Tabel.3

Pendapatan Pekerja

\begin{tabular}{|c|c|c|c|c|c|}
\hline No & $\begin{array}{c}\text { Nama } \\
\text { Pemilik Tobong }\end{array}$ & $\begin{array}{c}\text { Nama } \\
\text { Pekerja }\end{array}$ & $\begin{array}{c}\text { Upah Pokok } \\
\text { (Rp) }\end{array}$ & $\begin{array}{c}\text { Pembagian Upah } \\
\text { Cetak (Rp) }\end{array}$ & $\begin{array}{c}\text { Total Pendapatan } \\
\text { (Rp) }\end{array}$ \\
\hline \multirow[t]{2}{*}{1.} & Nidam & Tarsono & 1.200 .000 & 250.000 & 1.450 .000 \\
\hline & & Sulistiyono & 1.200 .000 & 250.000 & 1.450 .000 \\
\hline \multirow[t]{3}{*}{2.} & Sarkim & Sawin & 1.200 .000 & 280.000 & 1.480 .000 \\
\hline & & Hery & 1.200 .000 & 280.000 & 1.480 .000 \\
\hline & & Abdul & 1.200 .000 & 280.000 & 1.480 .000 \\
\hline \multirow[t]{3}{*}{3.} & Ruslan & Tugiyo & 1.200 .000 & 230.000 & 1.430 .000 \\
\hline & & Wardi & 1.200 .000 & 230.000 & 1.430 .000 \\
\hline & & Winardi & 1.200 .000 & 230.000 & 1.430 .000 \\
\hline \multirow[t]{3}{*}{4.} & Ranu M & Pujianto & 1.200 .000 & 250.000 & 1.450 .000 \\
\hline & & Panut & 1.200 .000 & 250.000 & 1.450 .000 \\
\hline & & Dikin & 1.200 .000 & 250.000 & 1.450 .000 \\
\hline \multirow[t]{3}{*}{5.} & Sarwin & Sawi & 1.200 .000 & 230.000 & 1.430 .00 \\
\hline & & Panto & 1.200 .000 & 230.000 & 1.430 .00 \\
\hline & & Pujianto & 1.200 .000 & 230.000 & 1.430 .00 \\
\hline \multirow[t]{3}{*}{6.} & Giman & Rahmanto & 1.200 .000 & 300.000 & 1.500 .000 \\
\hline & & Arsem & 1.200 .000 & 300.000 & 1.500 .000 \\
\hline & & Sudirwo & 1.200 .000 & 300.000 & 1.500 .000 \\
\hline \multirow[t]{2}{*}{7} & Sudar & Tumijan & 1.200 .000 & 305.000 & 1.505 .000 \\
\hline & & Paiman & 1.200 .000 & 305.000 & 1.505 .000 \\
\hline \multirow[t]{2}{*}{8} & Supardi & Sukiman & 1.200 .000 & 300.000 & 1.500 .000 \\
\hline & & Parlan & 1.200 .000 & 300.000 & 1.500 .000 \\
\hline
\end{tabular}

Sumber: diolah dari hasil kuisioner 
Kontribusi Pendapatan Masyarakat Terhadap Pendapatan Total Masyarakat

Menurut Arief (2012: 31), untuk mengukur besarnya kontribusi pendapatan dari usaha pembuatan batu bata terhadap ketahanan ekonomi keluarga, rumus yang diginakan adalah $\mathbf{N k}=\mathbf{P i} / \mathbf{P k}$ (Keterangan: $\mathrm{Nk}=$ Nilai Kontribusi; $\mathrm{Pi}=$ Pendapatan Usaha Pembuatan Batu Bata; $\mathrm{Pk}=$ Total Pendapatan).

Penilaian pendapatan terhadap kontribusi pendapatan warga yang mengikuti pemberdayaan masyarakat melalui usaha pembuatan batu bata dikategorikan dalam 3 (tiga) kategori, sebagaimana dalam tabel 4 di bawah ini.

Tabel 4

Kontribusi Pendapatan

\begin{tabular}{ccc}
\hline No & Nilai Kontribusi & Kategori \\
\hline 1 & $\leq 50 \%$ & Rendah \\
2 & $50 \%-99 \%$ & Tinggi \\
3 & $100 \%$ & Subsistensi / Mutlak \\
\hline
\end{tabular}

Sumber: Arief, 2012

Dari tabulasi dalam tabel 4 tersebut dapat disimpulkan hasil penghitungan nilai prosentasi dengan hasil 100\% merupakan kontribusi dalam tingkatan mutlak, nilai prosentasi lebih dari 50\% sampai $99 \%$ merupakan nilai kontribusi dalam tingkatan kategori tinggi, dan nilai prosentase kurang dari 50\% merupakan kontribusi kategori rendah. Untuk penghitungan kontribusi pendapatan melalui usaha pembuatan batu bata terhadap total pendapatan masyarakat yang terlibat di dalamnya dibahas di bawah ini.

\section{Kontribusi Terhadap Total Pendapatan Pemilik Usaha}

Total pendapatan pemilik usaha merupakan penjumlahan dari semua sumber penghasilan yang didapat pengusaha. Sumber penghasilan tersebut tidak hanya berasal dari usaha pembuatan batu bata, melainkan dari berbagai sumber lainnya. Dalam kuesioner disebutkan ada beberapa pekerjaan yang juga menghasilkan pendapatan bagi pengusaha selain dari usaha pembuatan batu bata. Hal tersebut terjadi karena sebelum menggeluti usaha pembuatan batu bata, para pemilik usaha merupakan orang-orang yang sudah memiliki pekerjaan. Jenis pekerjaan yang dijalani sebelumnya sangatlah beragam sebagaimana yang terlihat pada tabel 5 di bawah ini.

Tabel 5

Kontribusi Pendapatan Dari Usaha Batu Bata Terhadap Total Pendapatan

\begin{tabular}{lccccc}
\hline Nama & $\begin{array}{c}\text { Jenis Pekerjaan } \\
\text { Lain }\end{array}$ & $\begin{array}{c}\text { Pendapatan Lain } \\
\text { /bulan } \\
(\mathbf{R p})\end{array}$ & $\begin{array}{c}\text { Total Pendapatan } \\
\text { dari batu bata } \\
(\mathbf{R p})\end{array}$ & $\begin{array}{c}\text { Total Pendapatan } \\
\text { Keseluruhan } \\
(\mathbf{R p})\end{array}$ & $\begin{array}{c}\text { Nilai Kontribusi } \\
\mathbf{( \% )}\end{array}$ \\
\hline Nidam & Sadap nira & 750.000 & 2.330 .000 & 3.080 .000 & 75 \\
Sarkim & Petani & 1.000 .000 & 3.400 .000 & 4.400 .000 & 77 \\
Ruslan & Petani & 1.000 .000 & 2.735 .000 & 3.735 .000 & 73 \\
Ranu M & Pedagang & 1.500 .000 & 3.275 .000 & 4.775 .000 & 69 \\
Sarwin & Pedagang & 2.000 .000 & 2.735 .000 & 4.735 .000 & 58 \\
Giman & Petani & 1.000 .000 & 3.365 .000 & 4.365 .000 & 77 \\
Sudar & Petani & 1.000 .000 & 2.835 .000 & 3.835 .000 & 62 \\
Supardi & Petani & 1.000 .000 & 2.765 .000 & 3.765 .000 & 73 \\
\hline
\end{tabular}

Sumber : diolah dari hasil kuesioner dan wawancara 
Helmy Shoim Pramudyarto, Armaidy Armawi, Bagus Riyono -- Kepemimpinan Pemuda Dalam Program Pemberdayaan Masyarakat Untuk Meningkatkan Ketahanan Ekonomi Keluarga (Studi Kepemimpinan Wawan Yuanda di Desa Tumiyang, Kecamatan Kebasen, Kabupaten Banyumas, Provinsi Jawa Tengah)

Berdasarkan tabulasi pada tabel 5 tersebut dapat disimpulkan dalam tabel 6 berikut ini.

Tabel 6

\begin{tabular}{cccc}
\multicolumn{4}{c}{ Nilai Kontribusi Pemilik Usaha } \\
No & Nilai & Jumlah & Kategori \\
& Kontribusi & Pengusaha & Rendah \\
1 & $\leq 50 \%$ & - & Tinggi \\
2 & $50 \%-99 \%$ & 8 & Subsistensi / \\
3 & $100 \%$ & - & Mutlak \\
\hline
\end{tabular}

Sumber: Olahan Peneliti

Dari tabel 5 dan tabel 6 tersebut terlihat bahwa nilai kontribusi terbesar ialah 77 persen sedangkan yang paling rendah adalah 58 persen dan rata-rata nilai kontribusi ialah 70,5 persen. Hal ini menunjukkan bahwa para pengusaha pemilik tobong / usaha pembuatan batu bata memiliki jumlah penghasilan yang besar sehingga hal tersebut dapat mengangkat derajat kehidupan dalam segala hal. Hasil penghitungan kontribusi di atas mengandung makna bahwa pendapatan dari pembuatan batu bata cukup besar dibandingkan penghasilan dari usaha atau pekerjaan lain, sehingga dapat disimpulkan bahwa pembuatan batu bata memiliki kontribusi yang tinggi terhadap total pendapatan.

\section{Kontribusi Terhadap Total Pendapatan Pekerja}

Seperti halnya pada kondisi para pemilik usaha, para pekerja pada usaha pembuatan batu bata juga sudah memiliki pekerjaan sebelum ikut terlibat dalam program pemberdayaan melalui usaha pembuatan batu bata. Jenis pekerjaan dan besaran pendapatan terlihat pada tabel 7 di bawah ini :

Tabel 7

Kontribusi Pendapatan Dari Usaha Batu Bata Terhadap Total Pendapatan

\begin{tabular}{|c|c|c|c|c|c|}
\hline Nama & $\begin{array}{c}\text { Jenis Pekerjaan } \\
\text { Lain }\end{array}$ & $\begin{array}{c}\text { Pendapatan Lain } \\
\text { /bulan } \\
\text { (Rp) } \\
\end{array}$ & $\begin{array}{c}\text { Total Pendapatan } \\
\text { dari batu bata } \\
(\mathrm{Rp}) \\
\end{array}$ & $\begin{array}{c}\text { Total Pendapatan } \\
\text { Keseluruhan } \\
\text { (Rp) } \\
\end{array}$ & $\begin{array}{c}\text { Nilai Kontribusi } \\
(\%)\end{array}$ \\
\hline Tarsono & Buruh Tani & 500.000 & 1.450 .000 & 1.950 .000 & 74 \\
\hline Sulistiyono & Buruh Tani & 800.000 & 1.450 .000 & 2.250 .000 & 64 \\
\hline Sawin & Buruh Tani & 600.000 & 1.480 .000 & 2.080 .000 & 71 \\
\hline Hery & Buruh Tani & 600.000 & 1.480 .000 & 2.080 .000 & 71 \\
\hline Abdul & Buruh Tani & 600.000 & 1.480 .000 & 2.080 .000 & 71 \\
\hline Tugiyo & Buruh Tani & 400.000 & 1.430 .000 & 1.830 .000 & 78 \\
\hline Wardi & Buruh Tani & 500.000 & 1.430 .000 & 1.930 .000 & 74 \\
\hline Winardi & Buruh Tani & 400.000 & 1.430 .000 & 1.830 .000 & 78 \\
\hline Pujianto & Buruh Tani & 500.000 & 1.450 .000 & 1.950 .000 & 74 \\
\hline Panut & Buruh Tani & 400.000 & 1.450 .000 & 1.850 .000 & 78 \\
\hline Dikin & Buruh Tani & 500.000 & 1.450 .000 & 1.950 .000 & 74 \\
\hline Sawi & Buruh Tani & 500.000 & 1.430 .000 & 1.930 .000 & 74 \\
\hline Panto & Buruh Tani & 600.000 & 1.430 .000 & 2.030 .000 & 70 \\
\hline Pujianto & Buruh Tani & 600.000 & 1.430 .000 & 2.030 .000 & 70 \\
\hline Rahmanto & Buruh Tani & 500.000 & 1.500 .000 & 2.000 .000 & 75 \\
\hline Arsem & Buruh Tani & 600.000 & 1.500 .000 & 2.100 .000 & 71 \\
\hline Sudirwo & Buruh Tani & 500.000 & 1.500 .000 & 2.000 .000 & 75 \\
\hline Tumijan & Sadap nira & 500.000 & 1.505 .000 & 2.050 .000 & 73 \\
\hline Paiman & Buruh Tani & 600.000 & 1.505 .000 & 2.150 .000 & 70 \\
\hline Sukiman & Buruh Tani & 600.000 & 1.500 .000 & 2.150 .000 & 70 \\
\hline Parlan & tambang pasir & 1.500 .000 & 1.500 .000 & 3.000 .000 & 50 \\
\hline
\end{tabular}

Sumber : diolah dari hasil kuesioner dan wawancara 
Dari hasil tabulasi tabel 7 tersebut dapat diringkas dalam tabel 8 nilai kontribusi berikut ini.

Tabel 8

Nilai Kontribusi Pendapatan Pekerja

\begin{tabular}{cccc}
\hline No & $\begin{array}{c}\text { Nilai } \\
\text { Kontribusi }\end{array}$ & $\begin{array}{c}\text { Jumlah } \\
\text { Pekerja }\end{array}$ & Kategori \\
\hline 1 & $\leq 50 \%$ & 1 & Rendah \\
2 & $50 \%-99 \%$ & 20 & Tinggi \\
3 & $100 \%$ & - & $\begin{array}{c}\text { Subsistensi / } \\
\text { Mutlak }\end{array}$ \\
\hline
\end{tabular}

Sumber: Olahan Peneliti.

Dari tabel 7 dan tabel 8 tersebut dapat dilihat bahwa nilai kontribusi dari penghasilan pembuatan batu bata sangat signifikan atau besar dibandingkan sumber pendapatan dari pekerjaan lain. Dari hasil kedua tabel terlihat bahwa nilai kontribusi terbesar ialah pada angka 78 persen sedangkan yang terkecil ialah pada angka 50 persen dan rata-rata nilai kontribusi ialah 64,42 persen. Berdasarkan tabel tersebut sebanyak 20 orang pekerja masuk dalam kategori nilai kontribusi tinggi sedangkan hanya 1 pekerja yang nilai kontribusinya rendah. Seperti halnya pemilik usaha, bagi para pekerja pendapatan dari usaha pembuatan batu bata telah menjadi sumber pendapatan utama. Hal ini menjadi tolok ukur bahwa usaha pembuatan batu bata telah meningkatkan jumlah pendapatan masyarakat yang terlibat di dalamnya.

\section{Ketahanan Ekonomi Keluarga Berdasar Kriteria UMR Kabupaten Banyumas}

Salah satu indikator yang digunakan dalam menilai kekuatan ketahanan ekonomi keluarga pada penelitian ini menggunakan penghitungan dengan cara membandingkan antara besaran pendapatan dengan besaran UMR di Kabupaten Banyumas. Tahun 2015 pemerintah melalui peraturan gubernur telah menetapkan besaran UMR Kabupaten Banyumas sebesar Rp. 1.100.000,(Satu juta serratus rupiah)- sehingga uraian penilaian kekuatan ketahanan ekonomi keluarga pada masyarakat yang terlibat pada usaha pembuatan batu bata disajikan dalam uraian berikut.

Total Pendapatan Pemilik Usaha Dibandingkan dengan UMR Kabupaten Banyumas

Perbandingan antara total pendapatan dengan Upah Minimum Regional (UMR) digunakan sarana untuk menilai seberapa besar tingkat pendapatan serta gambaran akan pemenuhan kebutuhan masyarakat. Artinya semakin besar tingkat pendapatan masyarakat akan semakin besar pula kebutuhan yang dapat dipenuhi sehingga derajat kehidupan masyarakat dapat meningkat. Berikut adalah gambaran perbandingan total pendapatan masyarakat yang dibandingkan dengan UMR Kabupaten Banyumas yang telah ditetapkan oleh Gubernur Jawa Tengah melalui SK Gubernur no 665 Tahun 2014 yaitu sebesar Rp. 1.100.000,- (Satu juta seratus ribu rupiah). Untuk mengetahui seberapa tingkat perbandingan total pendapatan warga yang terlibat dalam usaha pembuatan batu bata dengan besaran UMR Kabupaten Banyumas ditampilkan dalam tabel 9 sebagai berikut.

Dari tabel 9 tersebut dapat disimpulkan bahwa pendapatan para pemilik usaha pembuatan batu bata berada di atas ratarata Upah Minimum Kabupaten Banyumas berdasarkan SK Gubernur no 665 Tahun 2014 yaitu sebesar Rp. 1.150.000, (Satu juta seratus lima puluh ribu rupiah) - dengan perbandingan nilai antara keduanya yang besar sehingga dapat dikatakan bahwa pengusaha dalam usaha pembuatan batu bata memiliki 
Helmy Shoim Pramudyarto, Armaidy Armawi, Bagus Riyono -- Kepemimpinan Pemuda Dalam Program Pemberdayaan Masyarakat Untuk Meningkatkan Ketahanan Ekonomi Keluarga (Studi Kepemimpinan Wawan Yuanda di Desa Tumiyang, Kecamatan Kebasen, Kabupaten Banyumas, Provinsi Jawa Tengah)

Tabel 9

Perbandingan Total Pendapatan Masyarakat Dengan UMR

\begin{tabular}{llcrr}
\hline No & Nama & $\begin{array}{c}\text { Total Pendapatan } \\
(\mathbf{R p})\end{array}$ & $\begin{array}{c}\text { Upah Minimum Regional } \\
\text { (UMR) } \\
(\mathbf{R p})\end{array}$ & $\begin{array}{c}\text { Perbandingan } \\
\text { Pendapatan dengan UMR }\end{array}$ \\
\hline 1 & Nidam & 3.080 .000 & 1.100 .000 & $2,67: 1$ \\
2 & Sarkim & 4.400 .000 & 1.100 .000 & $3,82: 1$ \\
3 & Ruslan & 3.735 .000 & 1.100 .000 & $3,25: 1$ \\
4 & Ranu Miharja & 4.775 .000 & 1.100 .000 & $4,15: 1$ \\
5 & Sarwin & 4.735 .000 & 1.100 .000 & $4,12: 1$ \\
6 & Giman & 4.365 .000 & 1.100 .000 & $3,79: 1$ \\
7 & Sudar & 3.835 .000 & 1.100 .000 & $3,33: 1$ \\
8 & Supardi & 3.765 .000 & 1.100 .000 & $3,27: 1$ \\
\hline
\end{tabular}

Sumber : diolah dari kuesioner dan wawancara

Tabel 10

Perbandingan Total Pendapatan Pekerja Dengan UMR

\begin{tabular}{|c|c|c|c|c|}
\hline No & Nama & $\begin{array}{l}\text { Total Pendapatan } \\
\text { (Rp) }\end{array}$ & $\begin{array}{c}\text { Upah Minimum Regional } \\
\text { (UMR) } \\
\text { (Rp) } \\
\end{array}$ & $\begin{array}{c}\text { Perbandingan } \\
\text { Pendapatan dengan UMR }\end{array}$ \\
\hline 1 & Tarsono & 1.950 .000 & 1.150 .000 & $1,69: 1$ \\
\hline 2 & Sulistiyono & 2.250 .000 & 1.150 .000 & $1,95: 1$ \\
\hline 3 & Sawin & 2.080 .000 & 1.150 .000 & $1,80: 1$ \\
\hline 4 & Hery & 2.080 .000 & 1.150 .000 & $1,80: 1$ \\
\hline 5 & Abdul & 2.080 .000 & 1.150 .000 & $1,80: 1$ \\
\hline 6 & Tugiyo & 1.830 .000 & 1.150 .000 & $1,59: 1$ \\
\hline 7 & Wardi & 1.930 .000 & 1.150 .000 & $1,67: 1$ \\
\hline 8 & Winardi & 1.830 .000 & 1.150 .000 & $1,59: 1$ \\
\hline 9 & Pujianto & 1.950 .000 & 1.150 .000 & $1,69: 1$ \\
\hline 10 & Panut & 1.850 .000 & 1.150 .000 & $1,60: 1$ \\
\hline 11 & Dikin & 1.950 .000 & 1.150 .000 & $1,69: 1$ \\
\hline 12 & Sawi & 1.930 .000 & 1.150 .000 & $1,67: 1$ \\
\hline 13 & Panto & 2.030 .000 & 1.150 .000 & $1,76: 1$ \\
\hline 14 & Pujianto & 2.030 .000 & 1.150 .000 & $1,76: 1$ \\
\hline 15 & Rahmanto & 2.000 .000 & 1.150 .000 & $1,73: 1$ \\
\hline 16 & Arsem & 2.100 .000 & 1.150 .000 & $1,82: 1$ \\
\hline 17 & Sudirwo & 2.000 .000 & 1.150 .000 & $1,73: 1$ \\
\hline 18 & Tumijan & 2.050 .000 & 1.150 .000 & $1,78: 1$ \\
\hline 19 & Paiman & 2.150 .000 & 1.150 .000 & $1,86: 1$ \\
\hline 20 & Sukiman & 2.150 .000 & 1.150 .000 & $1,86: 1$ \\
\hline 21 & Parlan & 3.000 .000 & 1.150 .000 & $2,60: 1$ \\
\hline
\end{tabular}

Sumber : diolah dari kuesioner dan wawancara

memiliki penghasilan yang layak.

Berdasarkan kategori yang digunakan dalam mengukur ketahanan ekonomi kelurga yang dihitung dengan membandingkan antara total pendapatan dengan Upah Minimum
Regional (UMR) maka ketahanan ekonomi keluarga pemilik usaha pembuatan batu bata termasuk dalam kategori baik. Hal ini dikarenakan jumlah pendapatan masyarakat lebih besar dibandingkan dengan UMR di 
Kabupaten Banyumas.

\section{Total Pendapatan Pekerja Dibandingkan} Dengan UMR Kabupaten Banyumas

Berdasarkan dasar kategori yang sama dengan yang diberlakukan dalam mengukur ketahanan ekonomi keluarga pemilik usaha di atas, maka untuk kategori pekerja, data mengenai perbandingan antara total pendapatan dengan UMR dapat dilihat pada tabel 10.

Dari tabel 10 tersebut dapat disimpulkan bahwa pendapatan para pekerja di usaha pembuatan batu bata berada di atas ratarata Upah Minimum Kabupaten Banyumas berdasarkan SK Gubernur no 665 Tahun 2014 yaitu sebesar Rp. 1.150.000,- (Satu Juta seratus lima puluh ribu rupiah). Tabel 10 tersebut juga menyajikan data bahwa total pendapatan masyarakat memberikan kontribusi besar sehingga menghasilkan perbandingan nilai antara total pendapatan dengan UMR.

Berdasarkan kategori yang digunakan dalam mengukur ketahanan ekonomi kelurga yang dihitung dengan membandingkan antara total pendapatan dengan Upah Minimum Regional (UMR) maka Ketahanan ekonomi keluarga pekerja pada usaha pembuatan batu bata termasuk dalam kategori baik. Hal ini ditunjukkan oleh besarnya pendapatan masyarakat dibandingkan dengan nilai UMR di Kabupaten Banyumas. Hasil penelitian ini selaras dengan penelitian yang dilakukan Oktafianti (2014) dimana dengan adanya program pemberdayaan masyarakat dapat meningkatkan jumlah pendapatan sehingga memberikan implikasi terhadap meningkatnya ketahanan ekonomi keluarga.

\section{Ketahanan Ekonomi Keluarga Berdasar} Kriteria Garis Kemiskinan Per Kapita
Selain menggunakana indikator Upah Minimum Regional (UMR) untuk mengukur seberapa kuat ketahanan ekonomi keluarga dalam penelitian ini, peneliti juga menggunakan kriteria pengukuran menggunakan standar garis kemiskinan yang telah ditetapkan oleh BPS. Pengukuran kekuatan ketahanan ekonomi keluarga dengan indikator standar garis kemiskinan ini dilakukan dengan membandingkan antara besaran porsi konsumsi per kapita anggota keluarga dengan besaran angka standar garis kemiskinan per kapita untuk kategori desa di kabupaten yang masuk di wilayah Provinsi Jawa Tengah. Berdasarkan publikasi BPS pada tahun 2015, garis kemiskinan per kapita untuk kategori desa di kabupaten yang masuk di wilayah Provinsi Jawa Tengah ialah di angka Rp. 310.395, (Tiga ratus sepuluh ribu tiga ratus Sembilan puluh lima rupiah)-. Pembahasan penilaian kekuatan ketahanan ekonomi keluarga pada masyarakat yang terlibat pada usaha pembuatan batu bata menggunakan indikator garis kemiskinan disajikan dalam uraian berikut.

\section{Perbandingan Antara Porsi Konsumsi Per Kapita Anggota Keluarga Pemilik Usaha Dengan Garis Kemiskinan Per Kapita}

Untuk menilai seberapa besar ketahanan ekonomi sebuah keluarga, peneliti menggunakan indikator yaitu indikator garis kemiskinan per kapita yang dibandingkan dengan porsi konsumsi per kapita anggota keluarga. Indikator tersebut merupakan gambaran mengenai standar dalam pemenuhan kebutuhan individu dalam kurun waktu satu bulan. Porsi konsumsi per kapita anggota keluarga merupakan hasil penghitungan dari jumlah pendapatan keluarga dibagi jumlah anggota keluarga. Sedangkan garis kemiskinan per kapita ditetapkan berdasarkan publikasi BPS pada tahun 2015, garis kemiskinan per 
Helmy Shoim Pramudyarto, Armaidy Armawi, Bagus Riyono -- Kepemimpinan Pemuda Dalam Program Pemberdayaan Masyarakat Untuk Meningkatkan Ketahanan Ekonomi Keluarga (Studi Kepemimpinan Wawan Yuanda di Desa Tumiyang, Kecamatan Kebasen, Kabupaten Banyumas, Provinsi Jawa Tengah)

kapita untuk kategori desa di kabupaten yang masuk di wilayah Provinsi Jawa Tengah ialah di angka Rp. 310.395,(Tiga ratus sepuluh ribu tiga ratus sembilan puluh lima rupiah)-. Perbandingan antara standar garis kemiskinan per kapita dengan porsi konsumsi per kapita anggota keluarga pemilik usaha batu bata di
Desa Tumiyang ditunjukkan tabel 11 sebagai berikut.

Dari tabel 11 tersebut dapat dilihat porsi konsumsi per kapita tertinggi adalah Rp. 1.100.000, (Satu juta seratus ribu rupiah) sedangkan yang terendah adalah Rp. 622.500, (Enam ratus dua puluh dua ribu lima ratus

Tabel 11

Perbandingan Antara Konsumsi Per Kapita Masyarakat Dengan Garis Kemiskinan

\begin{tabular}{llcccc}
\hline No & Nama & $\begin{array}{c}\text { Total Pendapatan } \\
\text { (Rp) }\end{array}$ & $\begin{array}{c}\text { Jumlah Keluarga } \\
\text { (orang) }\end{array}$ & $\begin{array}{c}\text { Porsi Konsumsi Per } \\
\text { Kapita } \\
\text { (Rp) }\end{array}$ & $\begin{array}{c}\text { Garis Kemiskinan } \\
\text { Per Kapita } \\
\text { (Rp) }\end{array}$ \\
\hline 1 Nidam & 3.080 .000 & 4 & 770.000 & 267.991 \\
2 & Sarkim & 4.400 .000 & 4 & 1.100 .000 & 267.991 \\
3 & Ruslan & 3.735 .000 & 6 & 622.500 & 267.991 \\
4 & Ranu M & 4.775 .000 & 5 & 955.000 & 267.991 \\
5 & Sarwin & 4.735 .000 & 9 & 526.000 & 267.991 \\
6 & Giman & 4.365 .000 & 4 & 1.091 .250 & 267.991 \\
7 & Sudar & 3.835 .000 & 4 & 958.750 & 267.991 \\
8 & Supardi & 3.765 .000 & 4 & 941.250 & 267.991 \\
\hline
\end{tabular}

Sumber : diolah dari kuesioner dan wawancara

Tabel 12

Perbandingan Antara Konsumsi Per Kapita Masyarakat Dengan Garis Kemiskinan

\begin{tabular}{|c|c|c|c|c|c|}
\hline No & Nama & $\begin{array}{c}\text { Total Pendapatan } \\
\text { (Rp) }\end{array}$ & $\begin{array}{c}\text { Jumlah Keluarga } \\
\text { (orang) }\end{array}$ & $\begin{array}{c}\text { Porsi Konsumsi Per } \\
\text { Kapita } \\
(\mathrm{Rp})\end{array}$ & $\begin{array}{c}\text { Garis Kemiskinan } \\
\text { Per Kapita } \\
\text { (Rp) } \\
\end{array}$ \\
\hline 1 & Tarsono & 1.950 .000 & 4 & 487.500 & 267.991 \\
\hline 2 & Sulistiyono & 2.250 .000 & 4 & 562.500 & 267.991 \\
\hline 3 & Sawin & 2.080 .000 & 3 & 693.000 & 267.991 \\
\hline 4 & Hery & 2.080 .000 & - & 2.080 .000 & 267.991 \\
\hline 5 & Abdul & 2.080 .000 & 6 & 347.000 & 267.991 \\
\hline 6 & Tugiyo & 1.830 .000 & 5 & 366.000 & 267.991 \\
\hline 7 & Wardi & 1.930 .000 & 4 & 482.500 & 267.991 \\
\hline 8 & Winardi & 1.830 .000 & 4 & 457.500 & 267.991 \\
\hline 9 & Pujianto & 1.950 .000 & 5 & 390.000 & 267.991 \\
\hline 10 & Panut & 1.850 .000 & 4 & 462.500 & 267.991 \\
\hline 11 & Dikin & 1.950 .000 & 3 & 650.000 & 267.991 \\
\hline 12 & Sawi & 1.930 .000 & 5 & 386.000 & 267.991 \\
\hline 13 & Panto & 2.030 .000 & 3 & 677.000 & 267.991 \\
\hline 14 & Pujianto & 2.030 .000 & 4 & 507.500 & 267.991 \\
\hline 15 & Rahmanto & 2.000 .000 & 5 & 400.000 & 267.991 \\
\hline 16 & Arsem & 2.100 .000 & 4 & 525.000 & 267.991 \\
\hline 17 & Sudirwo & 2.000 .000 & 3 & 667.000 & 267.991 \\
\hline 18 & Tumijan & 2.050 .000 & 4 & 512.500 & 267.991 \\
\hline 19 & Paiman & 2.150 .000 & 5 & 430.000 & 267.991 \\
\hline 20 & Sukiman & 2.150 .000 & 3 & 717.000 & 267.991 \\
\hline 21 & Parlan & 3.000 .000 & 5 & 600.000 & 267.991 \\
\hline
\end{tabular}

Sumber : data diolah dari kuesioner 
rupiah). Tabel 11 tersebut jelas menunjukkan bahwa keluarga pengusaha batu bata di Desa Tumiyang memiliki ketahanan ekonomi yang baik dikarenakan porsi konsumsi per kapita nilainya jauh di atas indeks garis kemiskinan per kapita yang telah ditetapkan oleh Badan Pusat Statistik (BPS). Diharapkan kesejahteraan warga dapat meningkat dengan program pembuatan batu bata tersebut.

\section{Perbandingan Antara Porsi Konsumsi Per Kapita Anggota Keluarga Pekerja Dengan Garis Kemiskinan Per Kapita}

Sedangkan data perbandingan antara konsumsi per kapita masyarakat dengan garis kemiskinan per kapita pada kategori pekerja dalam usaha pembuatan batu bata tersaji dalam tabel 12 .

Dari tabel 12 tersebut dapat dilihat porsi konsumsi per kapita tertinggi adalah Rp. 2.080.000, (Dua juta delapan puluh ribu rupiah) sedangkan yang terendah adalah Rp. 347.000 (Tigaratus Empat puluh tujuh ribu rupiah). Tabel 12 tersebut juga menunjukkan bahwa keluarga pekerja batu bata di Desa Tumiyang memiliki ketahanan ekonomi yang baik dikarenakan porsi konsumsi per kapita nilainya jauh di atas indeks garis kemiskinan per kapita yang telah ditetapkan oleh Badan Pusat Statistik (BPS). Kesejahteraan warga diharapkan dapat meningkat dengan program pembuatan batu bata tersebut.

\section{SIMPULAN}

Berdasar penjelasan tersebut di atas dapat ditarik simpulan sebagai berikut.

Pertama, Wawan Yuanda selaku Kepala Desa Tumiyang telah berhasil melakukan program pemberdayaan masyarakat melalui usaha batu bata. Wawan Yuanda berhasil memberikan contoh dalam memulai usaha pembuatan batu bata, bersosialisasi dengan warga agar mau memulai usaha. Selain itu warga yang telah terlibat dalam usaha pembuatan batu bata juga mendapat bimbingan dan pendampingan dari Wawan Yuanda.

Kedua, keberhasilan kepemimpinan Wawan Yuanda dalam program pemberdayaan masyarakat melalui usaha pembuatan batu bata dapat dibuktikan dengan meningkatkan jumlah pendapatan warga Desa Tumiyang yang terlibat di dalamnya. Bahkan usaha tersebut telah menjadi sumber pendapatan utama dibandingkan jenis pekerjaan lain yang ditekuni oleh warga. Dengan meningkatnya jumlah pendapatan warga tersebut memiliki dampak positif terhadap meningkatkan ketahanan ekonomi keluarga dari warga yang terlibat dalam usaha pembuatan batu bata. Hal ini terlihat dari besarnya jumlah pendapatan dibandingkan dengan UMR Kabupaten Banyumas serta porsi konsumsi per kapita anggota kelurga dari warga yang terlibat dalam usaha pembuatan batu bata lebih tinggi di atas garis kemiskinan per kapita untuk kategori desa di Provinsi Jawa Tengah pada tahun 2015.

Ketiga, dari pemaparan dua kriteria dalam menilai dampak dari pemberdayaan masyarakat melalui usaha pembuatan batu bata di atas dapat dikatakan bahwa usaha pembuatan batu bata memiliki peran dalam meningkatkan pendapatan sehingga dapat membantu menyejahterakan keluarga. Dalam kasus ini, program pemberdayaan masyarakat melalui usaha pembuatan batu bata ini telah menunjukkan bahwa pendapatan yang mereka peroleh dapat meningkatkan ketahanan ekonomi yang dibuktikan bahwa kondisi mereka berada di atas indeks garis kemiskinan per kapita yang telah ditetapkan oleh BPS serta pendapatan mereka berada di atas rata-rata UMR Kabupaten Banyumas. 
Helmy Shoim Pramudyarto, Armaidy Armawi, Bagus Riyono -- Kepemimpinan Pemuda Dalam Program Pemberdayaan Masyarakat Untuk Meningkatkan Ketahanan Ekonomi Keluarga (Studi Kepemimpinan Wawan Yuanda di Desa Tumiyang, Kecamatan Kebasen, Kabupaten Banyumas, Provinsi Jawa Tengah)

Keempat, masyarakat yang terlibat dalam program pemberdayaan masyarakat melalui usaha pembuatan batu bata telah menjadikan pekerjaan ini sebagai sumber pendapatan utama. Hal ini disebabkan karena jumlah pendapatan dari pekerjaan sebelumnya berada di bawah dari pendapatan melalui usaha pembuatan batu bata. Berdasarkan pembahasan tersebut dapat dikatakan bahwa selain mampu meningkatkan pendapatan dan meningkatkan ketahanan ekonomi keluarga, usaha pembuatan batu bata juga dapat menjadi sumber mata pencaharian utama masyarakat Desa Tumiyang.

Lebih lanjut, berdasarkan penelitian yang telah dilakukan, disampaikan beberapa rekomendasi sebagai berikut.

Pertama, kendala keuangan. Diharapkan dilakukan pendampingan agar masyarakat dapat merencanakan penggunaan uang dengan baik. Sebagai salah satu solusi, warga dapat mendirikan koperasi sebagai wadah bersama dalam menjalankan dan mengembangkan usaha utamanya untuk mengatasi masalah keuangan.

Kedua, kendala cuaca. Selain menyiapkan bangunan khusus untuk mengantisipasi cuaca, diharapkan juga adanya perbaikan sistem persedian. Warga harus mengoptimalkan produksi di musim kemarau sehingga memiliki persediaan utamanya persediaan batu bata siap bakar. Pada saat produksi menurun di musin penghujan warga dapat mengandalkan persedian batu bata siap bakar yang ada untuk memenuhi pesanan.

Ketiga, kendala bahan baku. Seiring sudah akan selesainya proyek pengeprasan tebing jalan di Desa Tumiyang maka semakin sedikit pula bahan baku yang dapat dimanfaatkan. Alternatif sumber bahan baku tanah harus ditemukan tentunya dengan pertimbangan nilai ekonomis yang sesuai.
Kendala ini harusnya juga menjadi gambaran bahwa usaha pembuatan batu bata tidak akan selamanya bisa dijalankan sehingga sebaiknya warga dengan keuntungan dan pengetahuannya mulai untuk mencari sumber pendapatan lainnya sembari mengembangkan usaha pembuatan batu bata.

Keempat, kendala pemasaran. Untuk mengatasi hal ini salah satu yang harus dilakukan ialah dengan melakukan upaya kerjasama dengan konsumen yang memiliki permintaan yang pasti, misal kerjasama dengan kontraktor atau toko bangunan.

\section{DAFTAR PUSTAKA}

Adisasmita, Rahardjo, 2006, Pembangunan Pedesaan dan Perkotaan, Yogyakarta: Graha Ilmu

Ancok, Djamaludin, 2012, Psikologi Kepemimpinan \& Inovasi. Jakarta: Penerbit Erlangga

Arief, Srituwa, 2012, Metodologi Penelitian Ekonomi. Jakarta: UI Press

Detik.com news.detik.com/berita/.../wawanyuwandha-menjadi-kepala-desa-di-umur25-tahun

Creswell, John. W., 2009, Research Design Pendekatan Kualitatif, Kuantitatif dan Mixed Edisi Ketiga. Yogyakarta: Pustaka Pelajar.

Garis Kemiskinan Menurut Provinsi 20132015, BPS diakses 9 Mei 2016 bappenas. go.id/download.php?id=8629

Oktavianti, Fanny Kartika. 2014. "Pendapatan Pembudidaya Ikan Anggota Kelompok Wirausaha Pemuda Dan Implikasinya Terhadap Ketahanan Ekonomi Keluarga (Studi Di Kelompok Wirausaha Pemuda Kota Palangka Raya, Provinsi Kalimantan Tengah)". Jurnal Ketahanan Nasional Vol 
20, No 3 (2014). Yogyakarta. Universitas Gadjah Mada.

Mardikanto, Totok. Soebiato, Poerwoko, 2011, Pemberdayaan Masyarakat Dalam Perspektif Kebijakan Publik, Bandung : Alfabeta.

Sumodiningrat, Gunawan, Refika, Aditama. 2007, Membangun Perekonomian Rakyat, Yogyakarta: Pustaka Pelajar.

\section{Peraturan Perundangan}

Undang-Undang Desa No. 6 Tahun 2014 diakses online 25 Mei 2013 www.dpr.go.id/ dokjdih/document/uu/UU_2014_6.pdf

\section{Wawancara}

1. Bapak Supardi

2. Bapak Sarkim

3. Bapak Sirun

4. Bapak Suryawinata

5. Bapak Ruslan

6. Bapak H. Budi

7. Bapak Nidam

8. Bapak Sudar

9. Bapak Giman 